J. Dairy Sci. 95:5317-5330

http://dx.doi.org/10.3168/jds.2012-5609

(C) American Dairy Science Association ${ }^{\circledR}, 2012$.

\title{
Meta-analysis of the effect of pregrazing pasture mass on pasture intake, milk production, and grazing behavior of dairy cows strip-grazing temperate grasslands
}

\author{
L. A. Pérez-Prieto* $†$ and R. Delagarde ${ }^{*} \dagger^{1}$ \\ *INRA, UMR1348, Physiologie, Environnement et Génétique pour l'Animal et les Systèmes d'Elevage (PEGASE), F-35590 Saint-Gilles, France \\ †Agrocampus Ouest, UMR1348, PEGASE, F-35000 Rennes, France
}

\begin{abstract}
Grazing management is a key factor in pasture-based dairy systems, which can be improved given advanced knowledge of the effects of pregrazing pasture mass (PM) on the performance of dairy cows. The aim of this study was to quantify the effects of PM on the pasture intake, milk production, milk composition, and grazing behavior of strip- or rotational-grazing dairy cows, based on a meta-analysis of published research papers. A database was created that included experiments in which the effects of PM on pasture intake and milk production of dairy cows were studied. Papers were selected only if at least 2 PM were compared under similar experimental conditions, particularly the same pasture allowance (SPA). The final database included 15 papers with 27 PM comparisons. For analytical purposes, the database was subdivided into 3 subsets that varied according to the estimation height at which pasture allowance was determined; that is, where PM were compared at the SPA above ground level $\left(\mathrm{SPA}_{0}\right.$ subset), above 2 to 3 $\mathrm{cm}\left(\mathrm{SPA}_{3}\right.$ subset), and above 4 to $5 \mathrm{~cm}$ ( $\mathrm{SPA}_{5}$ subset). Statistical analyses were conducted on the entire database (global analysis) and within each subset using linear model procedures. An interaction between PM and estimation height was found for pasture intake and milk production in the global analysis. On the basis of the predictive equations, pasture intake increased by $1.58 \mathrm{~kg}$ of dry matter/d per tonne increase in PM when $\mathrm{PM}$ were compared at $\mathrm{SPA}_{0}$, was not affected by PM when PM were compared at $\mathrm{SPA}_{3}$, and decreased by $0.65 \mathrm{~kg}$ of dry matter/d per tonne increase in $\mathrm{PM}$ when $\mathrm{PM}$ were compared at $\mathrm{SPA}_{5}$. This is consistent with the effect of PM on milk production, which was positive and negative (1.04 and $-0.79 \mathrm{~kg} / \mathrm{t}$ of PM, respectively) when PM were compared at $\mathrm{SPA}_{0}$ and $\mathrm{SPA}_{5}$, respectively. Grazing time was only slightly affected by PM,
\end{abstract}

Received April 10, 2012

Accepted May 16, 2012.

${ }^{1}$ Corresponding author: remy.delagarde@rennes.inra.fr irrespective of estimation height, because the effect of $\mathrm{PM}$ on pasture intake was mainly dependent on the variation in pasture intake rate. Pasture intake rate increased with increasing $\mathrm{PM}$ at $\mathrm{SPA}_{0}$ but decreased with increasing $\mathrm{PM}$ at $\mathrm{SPA}_{5}$. This meta-analysis clearly demonstrates that the effects of PM on pasture intake, milk production, and behavior of strip-grazing dairy cows depend largely on the height at which the PM and pasture allowance are measured. These results have methodological implications for future grazing research because it can be recommended that PM be compared at similar levels of pasture availability (i.e., at the same pasture allowance above 2 to $3 \mathrm{~cm}$ ) to avoid possible misinterpretations of results. They also reveal the benefits of improving grazing management and intake prediction through modeling in pasture-based dairy systems.

Key words: dairy cow, pasture mass, estimation height, meta-analysis

\section{INTRODUCTION}

Grazing management is a key factor in determining the efficiency of pasture-based dairy systems. It is recognized as the main tool for controlling pasture utilization and per-cow production, and reaching the optimal balance between these factors is the main objective for dairy farms trying to achieve maximum profitability. A major issue is, however, the lack of control over feed quality and availability throughout the year (Dillon et al., 2005). Large variation in pasture growth rate between seasons along with different practices in grazing management (e.g., rotation length or fertilization level) result in significant variation in pregrazing pasture mass (PM). Pregrazing PM is, therefore, directly related to farming decisions, and an advanced knowledge of its effect on pasture intake and milk production may be useful in improving grazing management in pasturebased dairy systems.

The effects of pregrazing sward height (i.e., PM) have been extensively studied under continuously 
stocked management, in which pasture intake and milk production were shown to decline with decreasing sward height (Rook et al., 1994; Gibb et al., 1997). In very short swards, cows are unable to fully compensate for the reduction in pasture intake rate by extending grazing time, and the daily pasture intake is penalized (Hodgson, 1986). Indeed, short-term pasture intake rate decreases with decreasing PM because of the strong reduction in bite mass, which is only partially compensated for by the increase in biting rate (Hodgson, 1986; Ungar, 1996). In contrast, few such studies have been conducted under strip-grazing management, with Delagarde et al. (2001) being the first to review the effect of PM on pasture intake. Furthermore, no previous meta-analysis has investigated the effect of PM on pasture intake, nor has any review or meta-analysis studied the effect of PM on milk production or on the grazing behavior of strip-grazing dairy cows.

Under strip- or rotational-grazing management, intake and milk production are primarily affected by pasture allowance (PA), that is, the product of PM and daily offered area (Peyraud et al., 1996; Dalley et al., 1999; Maher et al., 2003). Under such grazing systems, the daily offered area is a limiting factor, and the effect of pregrazing PM is generally studied by comparing 2 or more PM at similar PA. However, the height above which PM and PA are expressed (i.e., estimation height) is variable and depends on grazing management practices. In New Zealand and Australia, PM and PA are normally estimated by cutting pastures manually with electric shears at ground level (Holmes et al., 1992; Wales et al., 1999). In European countries, such as France and Ireland, pasture is usually sampled by cutting strips with a motor scythe at 4 or $5 \mathrm{~cm}$ above ground level (Ribeiro Filho et al., 2003; Wims et al., 2010), but can also be sampled at ground level (Stakelum, 1986a; Peyraud et al., 1996) or at 2 or $3 \mathrm{~cm}$ above ground level (Stakelum and Dillon, 2004; PérezPrieto et al., 2011). Previous reviews (Baudracco et al., 2011; Delagarde et al., 2011b) demonstrated that the estimation height has a direct and mechanical effect on the relationship between pasture intake and PA, this being a consequence of pasture bulk density, which increases from the top to the bottom of the sward profile. The pasture intake/PA slope is lower, with an estimation height of 4 to $5 \mathrm{~cm}$ above ground level. Delagarde et al. (2001) suggested a similar effect of the estimation height on the relationship between pasture intake and PM. They proposed, based on a literature review, that pasture intake increases with increasing PM when PM are compared at the same PA (SPA) above ground level $\left(\mathbf{S P A}_{\mathbf{0}}\right)$, whereas pasture intake decreases with increasing PM when PM are compared at the SPA above 4 or $5 \mathrm{~cm}\left(\mathbf{S P A}_{5}\right)$. They also suggested that PM had no effect on pasture intake when PM are compared at the SPA above an intermediate height, namely, above 2 to $3 \mathrm{~cm}\left(\mathbf{S P A}_{\mathbf{3}}\right)$. This hypothesis was then used as a basis for the GrazeIn model used to predict pasture intake by dairy cows (Delagarde et al., 2011a). The external validation of the GrazeIn model when using a large independent data set showed no relationship between the intake bias (predicted minus actual) and the pregrazing PM over a wide range of PM, suggesting the hypothesis was correct (Delagarde et al., 2011b). Recently, Pérez-Prieto et al. (2012) has also confirmed this hypothesis under experimental grazing conditions in which $2 \mathrm{PM}$ were compared simultaneously at $\mathrm{SPA}_{0}$, $\mathrm{SPA}_{3}$, and $\mathrm{SPA}_{5}$.

The objective of the present work was to perform a meta-analysis of the effect of pregrazing PM on pasture intake, milk production, milk composition, and grazing behavior of strip-grazing dairy cows. In particular, the study aimed to determine if the effect of PM was related to the estimation height at which PM and PA were measured. Predictive equations derived from this investigation will allow for a better understanding of the effects of PM, which will in turn be useful knowledge for modeling the intake and performance of dairy cows, and to improve grazing management in pasturebased dairy systems.

\section{MATERIALS AND METHODS}

\section{Literature Search and Data Entry}

A computerized literature search (Agricola, CAB Abstracts, and Web of Science) was conducted to identify papers in which the effects of pregrazing PM on the pasture intake or milk production of dairy cows were studied. The search was carried out using different combinations of the following key words: dairy cow, grazing, mass, herbage, pasture. Further papers were then selected by reviewing the reference lists in the publications resulting from the initial search. Papers were chosen if they met the following criteria: (1) included temperate regions and temperate sward species, (2) included lactating dairy cows under strip- or rotational-grazing management, (3) included a comparison of at least $2 \mathrm{PM}$ under similar experimental conditions, particularly at the SPA. After discarding publications with duplicate data (i.e., results from the same experiment published several times), a starting database was constructed that included 19 papers and 48 PM comparisons. The database was conceptualized with rows representing treatments within an experiment and columns reporting treatment characteristics and least squares means of measured variables. Each paper was categorized by author name(s), year of pub- 
lication, and country. Each PM comparison was allocated an individual code (study) and was characterized by grazing system, season, pasture type, experimental design, experimental duration, number of cows, preexperimental cow characteristics, estimation height, and the method used to estimate pasture intake. The cutting instrument used to measure pregrazing PM was also included as a characteristic for each PM comparison. The authors were contacted personally, whenever possible, to inquire about this information when it was not reported in their paper. In experiments in which the interaction between PM and another factor was studied (e.g., at 2 supplementation levels or 2 fertilization levels), PM comparisons conducted under similar experimental conditions were considered independent studies.

\section{Data Filtering}

Investigations solely reporting PM comparisons carried out with minimal concentrate $(<1 \mathrm{~kg}$ of $\mathrm{DM} / \mathrm{d})$ and no forage supplementation were selected $(\mathrm{n}=7$, number of studies eliminated). Furthermore, studies including very high PM (i.e., $>4.0 \mathrm{t}$ of $\mathrm{DM} /$ ha above $5 \mathrm{~cm}$ or $>7.0 \mathrm{t}$ of DM/ha above ground level, approximately) or with very low pasture quality at high PM were rejected because of the risk of accumulated effects between PM and pasture quality $(\mathrm{n}=7)$. Additionally, studies were excluded if the difference between $\mathrm{PM}$ treatments was less than $0.7 \mathrm{t}$ of $\mathrm{DM} / \mathrm{ha}(\mathrm{n}=4)$ or because of inconsistencies in pasture intake results regarding animal characteristics and milk production $(\mathrm{n}=3)$.

\section{Calculations}

At least 2 of the following 3 parameters were needed to calculate the remaining parameters: PM, PA, and offered area $(\mathrm{PA}=\mathrm{PM} \times$ daily offered area $)$. Data were standardized before quantitative and statistical analyses. Pregrazing PM and PA were expressed in tonnes of DM per hectare and kilogram of DM per cow per day, respectively. The database included papers in which PM and PA were estimated above ground level and at $2.5,3,4,4.5$, or $5 \mathrm{~cm}$. For analytical purposes, the database was divided into 3 subsets: PM compared at $\mathrm{SPA}_{0}\left(\mathrm{SPA}_{0}\right.$ subset), PM compared at the SPA above 2.5 or $3 \mathrm{~cm}$ ( $\mathrm{SPA}_{3}$ subset), and $\mathrm{PM}$ compared at the SPA above $4,4.5$, or $5 \mathrm{~cm}\left(\mathrm{SPA}_{5}\right.$ subset). In the $\mathrm{SPA}_{3}$ subset, PM and PA above $2.5 \mathrm{~cm}$ were standardized and recalculated above $3 \mathrm{~cm}$. In the $\mathrm{SPA}_{5}$ subset, $\mathrm{PM}$ and PA above 4 and $4.5 \mathrm{~cm}$ were standardized and recalculated above $5 \mathrm{~cm}$. This was done according to the following general equations calibrated from a large data set including pure perennial ryegrass and ryegrass/white clover pastures, reported in or modified from Delagarde et al. (2011a):

$$
\begin{gathered}
\mathrm{PM}_{0}=1.06 \times \mathrm{PM}_{2.5}+1,452, \\
\mathrm{PM}_{0}=1.13 \times \mathrm{PM}_{4}+1,903, \\
\mathrm{PM}_{0}=1.15 \times \mathrm{PM}_{4.5}+2,021, \\
\mathrm{PM}_{3}=0.92 \times \mathrm{PM}_{0}-1,499, \\
\mathrm{PM}_{5}=0.85 \times \mathrm{PM}_{0}-1,811,
\end{gathered}
$$

where $\mathrm{PM}_{0}, \mathrm{PM}_{2.5}, \mathrm{PM}_{3}, \mathrm{PM}_{4}, \mathrm{PM}_{4.5}$, and $\mathrm{PM}_{5}$ are pregrazing PM above ground level and at 2.5, 3, 4, 4.5, and $5 \mathrm{~cm}$, respectively.

For subsequent global analysis, the database was reorganized, creating a second database (slopes database). This was based on the within-experiment slopes of the relationship between PM and the dependent variables. In each PM comparison, slopes were calculated by dividing the difference between the values of the dependent variable in the highest and the lowest PM by the difference between the highest and the lowest PM (expressed as per-tonne increase in PM). This methodology enabled a comparison of the effect of PM between studies and, hence, between the estimation heights without any correction of absolute PM values.

Fat-corrected milk production $(4 \% \mathrm{FCM})$ was calculated according to the method of INRA (2007). Daily average pasture intake rate $(\mathrm{g}$ of $\mathrm{DM} / \mathrm{min}$ ) was calculated by dividing pasture intake $(\mathrm{kg}$ of $\mathrm{DM} / \mathrm{d})$ by grazing time $(\mathrm{min} / \mathrm{d})$.

\section{Statistical Analyses}

Statistical analyses were conducted independently in the $\mathrm{SPA}_{0}, \mathrm{SPA}_{3}$, and $\mathrm{SPA}_{5}$ subsets. The study effect was considered random and a structured variancecovariance matrix for the intercepts and slopes was included (random covariance not significant; St-Pierre, 2001). Data were analyzed using the following model (PROC MIXED; SAS Institute, 1999):

$$
R_{y}=\mathrm{a}+\text { study }+\mathrm{b} \times \mathrm{PM},
$$

where $R_{y}$ is the predicted variable $y$ in response to the pregrazing change in PM, a is the overall intercept, study is the random effect of the study (PM comparison), and b is the overall linear regression coefficient. The overall quadratic regression coefficient was tested 
but not included in the final analyses because it was not significant in all subsets $(P>0.05)$.

The overall intercepts, the overall regression linear coefficients, and standard deviations are reported for all data in which the regression from the mixed model was significant (i.e., $P<0.10$ ). Observations adjusted for the study effect were calculated according to the method of St-Pierre (2001) by using the following equation: $\mathrm{Y}$ adjusted $=\mathrm{Y}$ predicted + residual. The $\mathrm{Y}$ predicted are the $\mathrm{Y}$ values on the regression line calculated with the mixed model.

In addition, a global analysis was performed that included data in the slopes database to test the fixed effect of the estimation height (i.e., PM compared at $\mathrm{SPA}_{0}, \mathrm{SPA}_{3}$, and $\mathrm{SPA}_{5}$ ) on the dependent variable/PM slopes. Data were analyzed using the following model (PROC GLM; SAS Institute, 1999):

$$
\mathrm{Y}_{\mathrm{ijk}}=\mu+\text { estimation height }+e_{\mathrm{ijk}},
$$

where $\mathrm{Y}_{\mathrm{ijk}}, \mu$, estimation height, and $e_{\mathrm{ijk}}$ represent the analyzed variable, the overall mean, the fixed effect of the estimation height, and the residual standard error term, respectively. The linear and quadratic effects of the estimation height were tested by orthogonal contrasts. The least squares means and standard deviations are reported for all data in which the regression from the linear model was significant (i.e., $P<0.10$ ).

\section{RESULTS}

\section{Database Description}

The final PM database was composed of 15 experiments taken from 15 papers published between 1986 and 2012, with 27 PM comparisons (23 between 2 PM and 4 between 3 PM; Table 1). The grazing system was solely strip-grazing (27), predominantly on perennial ryegrass swards (18) or mixed perennial ryegrass/ white clover swards (9). Pasture intake was determined either by a sward-sampling technique (12), indirectly from fecal output and pasture digestibility (5), or by using the $n$-alkanes technique (9). The pasture intake methodology was, however, not reported in one paper. The studies were reported from Ireland, France, Australia, New Zealand, and the United Kingdom. The effect of PM was studied at $\mathrm{SPA}_{0}(11$; in Ireland, New Zealand, Australia, and France), at $\mathrm{SPA}_{3}$ (3; in Ireland and France), and at $\mathrm{SPA}_{5}$ (13; in the United Kingdom, Ireland, and France; Table 1). Motor-driven sheepshearing handpieces, sheep shearers, or scissors were the instruments used to cut pastures to ground level, electric hand shears or a rotary mower was used to cut above 2.5 or $3 \mathrm{~cm}$, and a motor scythe or an auto scythe was used to cut above 4 or $5 \mathrm{~cm}$. All studies were carried out in the spring or summer, and the experimental design was either continuous (17), Latin square (5), or simple switchback (5). The number of cows in each PM comparison varied from 6 to 68, mainly according to the experimental design. The average low and high PM were 3.2 and $4.7 \mathrm{t}$ of $\mathrm{DM} / \mathrm{ha}$ in the $\mathrm{SPA}_{0}$ subset, 2.1 and $4.0 \mathrm{t}$ of $\mathrm{DM} /$ ha in the $\mathrm{SPA}_{3}$ subset, and 1.7 and 3.2 $\mathrm{t}$ of $\mathrm{DM} /$ ha in the $\mathrm{SPA}_{5}$ subset, respectively.

Cow characteristics were similar between subsets, with the variation in BW (505 to $559 \mathrm{~kg}$ ), stage of lactation (84 to 145 DIM), milk production (19.8 to 24.7 $\mathrm{kg} / \mathrm{d}$ ), and pasture intake (14.7 to $16.2 \mathrm{~kg}$ of $\mathrm{DM} / \mathrm{d}$ ) being relatively low (Table 2). The mean durations of the experiments were 3,8 , and 9 wk in the $\mathrm{SPA}_{0}$, $\mathrm{SPA}_{3}$, and $\mathrm{SPA}_{5}$ subsets, respectively. Pasture allowance averaged $31 \mathrm{~kg}$ of $\mathrm{DM} / \mathrm{d}$ above ground level, 19 $\mathrm{kg}$ of $\mathrm{DM} / \mathrm{d}$ above $3 \mathrm{~cm}$, and $17 \mathrm{~kg}$ of $\mathrm{DM} / \mathrm{d}$ above 5 $\mathrm{cm}$ in the $\mathrm{SPA}_{0}, \mathrm{SPA}_{3}$, and $\mathrm{SPA}_{5}$ subsets, respectively. Pasture digestibility averaged $781 \mathrm{~g} / \mathrm{kg}$ and was similar between subsets and between PM within each subset. Fewer results were available for milk production than for pasture intake, except in the $\mathrm{SPA}_{5}$ subset, in which the amount of data for milk production was greater. Data collected on the grazing behavior were scarce, varying from 2 to 13 depending on the studied variable and subset (Table 2).

\section{Effect of Pregrazing PM in the SPA $A_{0}$ Subset}

When PM were compared at $\mathrm{SPA}_{0}$, pasture intake increased with increasing PM in all the PM comparisons of this subset, except one (Figure 1A). On the basis of the predictive equations, pasture intake increased linearly by $1.58 \mathrm{~kg} / \mathrm{t}$ of PM $(P<0.01$; Table 3$)$, and milk production appeared to increase with increasing PM $(+1.04 \mathrm{~kg} / \mathrm{t}$ of PM; $P=0.08$; Figure $2 \mathrm{~A})$. Grazing time was not affected by $\mathrm{PM}$, and herbage intake rate increased by $4.83 \mathrm{~g}$ of $\mathrm{DM} / \mathrm{min}$ per tonne of PM $(P<$ $0.01)$.

\section{Effect of Pregrazing PM in the $\mathrm{SPA}_{3}$ Subset}

The mixed model was significant only for pasture intake, grazing time, and pasture intake rate $(P<0.10$; Table 3). On the basis of the predictive equations, PM had no effect on pasture intake $(P>0.10$; Figure 1B). Grazing time tended to decrease $(-22 \mathrm{~min} / \mathrm{t}$ of PM; $P$ $=0.07)$, whereas pasture intake rate tended to increase $(+1.6 \mathrm{~g}$ of $\mathrm{DM} / \mathrm{min}$ per tonne of PM; $P=0.08)$ with increasing PM. 
Table 1. Summary of the 27 pasture mass (PM) comparisons included in the meta-analysis to determine the effect of pregrazing PM on pasture intake, milk production, and

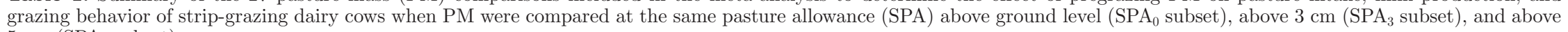
$5 \mathrm{~cm}\left(\mathrm{SPA}_{5}\right.$ subset$)$

\begin{tabular}{|c|c|c|c|c|c|c|c|c|c|c|c|c|c|}
\hline \multirow[b]{2}{*}{ Reference } & \multirow[b]{2}{*}{ Country $^{1}$} & \multirow[b]{2}{*}{$\underset{\mathrm{cm}}{\mathrm{EH}}$} & \multirow[b]{2}{*}{$\begin{array}{l}\text { Cutting } \\
\text { instrument }^{3}\end{array}$} & \multirow[b]{2}{*}{$\begin{array}{c}\mathrm{PM} \\
\text { comp. }\end{array}$} & \multirow[b]{2}{*}{$\mathrm{Ss}^{5}$} & \multirow[b]{2}{*}{$\begin{array}{l}\text { No. of } \\
\text { cows }^{6}\end{array}$} & \multirow[b]{2}{*}{$\operatorname{Design}^{7}$} & \multirow[b]{2}{*}{ Parity $^{8}$} & \multirow[b]{2}{*}{$\mathrm{DIM}^{9}$} & \multicolumn{3}{|c|}{$\mathrm{PM},{ }^{10} \mathrm{t}$ of $\mathrm{DM} / \mathrm{ha}$} & \multirow[b]{2}{*}{$\begin{array}{l}\text { Concentrate, } \\
\mathrm{kg} \text { of } \mathrm{DM} / \mathrm{d}\end{array}$} \\
\hline & & & & & & & & & & Lowest & Highest & Dif. & \\
\hline \multicolumn{14}{|l|}{$\mathrm{SPA}_{0}$ subset } \\
\hline Stakelum (1986a) & IE & 0.0 & MDSH & 2 & Spr. & 40 & CT & All & 83 & 3.2 & 3.9 & 0.7 & 0.0 \\
\hline Stakelum (1986b) & IE & 0.0 & MDSH & 2 & Sum. & 40 & $\mathrm{CT}$ & Mult. & 196 & 3.7 & 4.7 & 1.0 & 0.0 \\
\hline Holmes et al. (1992) & $\mathrm{NZ}$ & 0.0 & MDSH & 1 & Spr. & 20 & $\mathrm{CT}$ & NR & 29 & 2.8 & 5.5 & 2.7 & 0.0 \\
\hline Wales et al. (1999) & $\mathrm{AU}$ & 0.0 & Sheep shearer & 4 & Spr. & 48 & $\mathrm{CT}$ & Mult. & 36 & 3.1 & 4.9 & 1.8 & 0.0 \\
\hline Lee et al. (2008) & NZ & 0.0 & MDSH & 1 & Spr. & 30 & $\mathrm{CT}$ & Mult. & 59 & 2.8 & 3.9 & 1.1 & 0.0 \\
\hline Pérez-Prieto et al. (2012) & $\mathrm{FR}$ & 0.0 & Scissors & 1 & Spr. & 8 & SB & All & 147 & 3.5 & 5.4 & 1.9 & 0.0 \\
\hline \multicolumn{14}{|l|}{$\mathrm{SPA}_{3}$ subset } \\
\hline Stakelum and Dillon (2004) & IE & 3.0 & Rotary mower & 2 & Spr. & 12 & LS & Mult. & 91 & 2.2 & 3.7 & 1.5 & 0.0 \\
\hline Pérez-Prieto et al. (2012) & $\mathrm{FR}$ & 2.5 & EMS & 1 & Spr. & 8 & SB & All & 147 & 2.0 & 4.2 & 2.2 & 0.0 \\
\hline \multicolumn{14}{|l|}{$\mathrm{SPA}_{5}$ subset } \\
\hline Christie et al. (2000) & UK & 4.0 & UN & 1 & Spr. & 36 & $\mathrm{CT}$ & Mult. & 129 & 2.5 & 3.5 & 1.0 & 0.0 \\
\hline Parga et al. (2002) & FR & 5.0 & Motor scythe & 2 & Spr. & 12 & LS & Mult. & 186 & 1.3 & 3.8 & 2.5 & 0.2 \\
\hline Ribeiro Filho et al. (2003) & FR & 5.0 & Motor scythe & 1 & Spr. & 6 & LS & All & 218 & 1.2 & 3.3 & 2.1 & 0.3 \\
\hline Delagarde et al. (2004) & FR & 5.0 & Motor scythe & 2 & Spr. & 12 & $\mathrm{SB}$ & Mult. & 185 & 2.2 & 3.7 & 1.5 & 0.2 \\
\hline Stakelum and Dillon (2007) & IE & 4.5 & Motor scythe & 1 & Sum. & 42 & $\mathrm{CT}$ & NR & 154 & 2.4 & 3.4 & 1.0 & 0.0 \\
\hline Curran et al. (2010) & IE & 4.0 & Auto scythe & 2 & Sum. & 64 & $\mathrm{CT}$ & All & 58 & 1.5 & 2.8 & 1.3 & 0.0 \\
\hline Wims et al. (2010) & $\mathrm{IE}$ & 4.0 & Auto scythe & 1 & Spr. & 46 & $\mathrm{CT}$ & All & 46 & 1.1 & 2.0 & 0.9 & 0.0 \\
\hline McEvoy et al. (2010) & IE & 4.0 & Auto scythe & 2 & Sum. & 68 & $\mathrm{CT}$ & All & 118 & 1.7 & 2.8 & 1.1 & 0.0 \\
\hline Pérez-Prieto et al. (2012) & FR & 5.0 & Motor scythe & 1 & Spr. & 8 & SB & All & 147 & 1.0 & 3.6 & 2.6 & 0.0 \\
\hline
\end{tabular}

${ }^{1}$ Country codes as given in ISO 3166-1: IE = Ireland; NZ = New Zealand; AU = Australia; FR = France; UK = United Kingdom

${ }^{2} \mathrm{EH}=$ estimation height (i.e., height above which PM and pasture allowance were estimated).

${ }^{3} \mathrm{MDSH}=$ motor-driven sheep-shearing handpiece; EMS = electric manual shears; UN = unknown.

c $\quad{ }^{4}$ Number of PM comparisons considered from each paper.

${ }^{5} \mathrm{Ss}=$ season; Spr. = spring; Sum. = summer.

을 $\quad{ }^{6}$ Number of cows used in the PM comparison(s) considered from each paper.

글 ${ }^{7}$ Experimental design: $\mathrm{CT}=$ continuous; $\mathrm{SB}=$ switchback; $\mathrm{LS}=$ Latin square

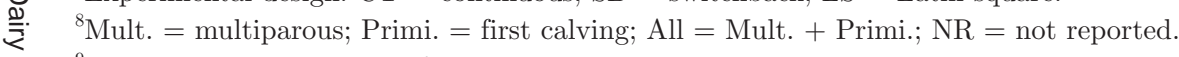

() ${ }^{9} \mathrm{DIM}=\mathrm{DIM}$ at the start of treatment.

$\frac{\Gamma}{\bar{D}}$. ${ }^{10} \mathrm{PM}$ above ground level in the $\mathrm{SPA}_{0}$ subset, above $3 \mathrm{~cm}$ in the $\mathrm{SPA}_{3}$ subset, and above $5 \mathrm{~cm}$ in the $\mathrm{SPA}_{5}$ subset; Dif. = within-experiment difference between the lowest and highest PM. 
Table 2. Summary statistics of the studies included in the meta-analysis to determine the effect of pregrazing pasture mass (PM) on pasture intake, milk production, and grazing behavior of strip-grazing dairy cows when compared at the same pasture allowance ( $\mathrm{SPA})$ above ground level $\left(\mathrm{SPA}_{0} \mathrm{subset}\right.$, above $3 \mathrm{~cm}\left(\mathrm{SPA}_{3}\right.$ subset), and above $5 \mathrm{~cm}\left(\mathrm{SPA}_{5}\right.$ subset $)^{1}$

\begin{tabular}{|c|c|c|c|c|c|c|c|c|c|c|c|c|c|c|c|}
\hline \multirow[b]{2}{*}{ Item } & \multicolumn{5}{|c|}{$\mathrm{SPA}_{0}$ subset } & \multicolumn{5}{|c|}{$\mathrm{SPA}_{3}$ subset } & \multicolumn{5}{|c|}{$\mathrm{SPA}_{5}$ subset } \\
\hline & $\mathrm{n}$ & Mean & $\mathrm{SD}$ & Min & Max & $\mathrm{n}$ & Mean & $\mathrm{SD}$ & Min & $\operatorname{Max}$ & $\mathrm{n}$ & Mean & $\mathrm{SD}$ & Min & $\operatorname{Max}$ \\
\hline Experiment length, wk & 23 & 4 & 1.3 & 2 & 5 & 6 & 9 & 4.1 & 4 & 12 & 29 & 8 & 3.5 & 4 & 15 \\
\hline DIM at start of treatment & 23 & 84 & 62.0 & 29 & 197 & 6 & 110 & 28.9 & 91 & 147 & 29 & 145 & 52.8 & 46 & 218 \\
\hline $\mathrm{BW}, \mathrm{kg}$ & 23 & 505 & 41.3 & 425 & 579 & 6 & 537 & 30.7 & 517 & 584 & 29 & 559 & 38.0 & 495 & 609 \\
\hline $\mathrm{PM},{ }^{2} \mathrm{t}$ of $\mathrm{DM} / \mathrm{ha}$ & 23 & 3.9 & 0.87 & 2.8 & 5.5 & 6 & 2.9 & 0.89 & 1.8 & 3.7 & 29 & 2.3 & 0.93 & 0.8 & 3.8 \\
\hline $\begin{array}{l}\text { Pasture allowance, }{ }^{3} \mathrm{~kg} \text { of DM/d } \\
\text { Digestibilitv }{ }^{4} \mathrm{~g} / \mathrm{kg}\end{array}$ & 23 & 31 & 15.6 & 15 & 70 & 6 & 19 & 4.0 & 14 & 22 & 29 & 17 & 5.7 & 11 & 31 \\
\hline Low PM & 11 & 752 & 50.5 & 700 & 850 & 3 & 810 & 38.7 & 765 & 832 & 9 & 797 & 34.2 & 763 & 855 \\
\hline High PM & 11 & 765 & 50.3 & 700 & 871 & 3 & 794 & 21.4 & 769 & 806 & 9 & 769 & 45.7 & 711 & 829 \\
\hline Pasture intake, $\mathrm{kg}$ of $\mathrm{DM} / \mathrm{d}$ & 23 & 14.7 & 3.05 & 6.7 & 22.3 & 6 & 15.3 & 1.98 & 12.7 & 16.8 & 24 & 16.2 & 1.24 & 14.1 & 18.6 \\
\hline Milk production, $\mathrm{kg} / \mathrm{d}$ & 15 & 24.7 & 3.23 & 19.9 & 32.0 & 2 & 24.6 & 0.71 & 24.1 & 25.1 & 29 & 19.8 & 4.03 & 9.6 & 26.9 \\
\hline Milk fat concentration, $\mathrm{g} / \mathrm{kg}$ & 7 & 40.6 & 2.18 & 37.8 & 44.2 & 2 & 37.5 & 0.41 & 37.0 & 37.9 & 23 & 39.1 & 2.15 & 36.1 & 44.7 \\
\hline Milk protein concentration, $\mathrm{g} / \mathrm{kg}$ & 7 & 32.1 & 1.23 & 30.6 & 33.7 & 2 & 31.5 & 0.21 & 31.3 & 31.6 & 23 & 33.0 & 1.91 & 30.0 & 37.4 \\
\hline $4 \%$ FCM production, $\mathrm{kg} / \mathrm{d}$ & 7 & 23.0 & 1.84 & 20.0 & 25.3 & 2 & 23.7 & 0.45 & 23.3 & 24.0 & 23 & 19.9 & 4.48 & 9.5 & 27.7 \\
\hline Milk fat production, $\mathrm{g} / \mathrm{d}$ & 7 & 924 & 74.1 & 800 & 1,021 & 2 & 921 & 10.8 & 913 & 928 & 23 & 788 & 183.0 & 377 & 1,130 \\
\hline Milk protein production, $\mathrm{g} / \mathrm{d}$ & 7 & 731 & 48.7 & 670 & 817 & 2 & 774 & 27.5 & 754 & 793 & 23 & 660 & 145.2 & 359 & 896 \\
\hline Grazing time, $\min / \mathrm{d}$ & 10 & 481 & 43.7 & 402 & 545 & 6 & 520 & 31.1 & 480 & 557 & 13 & 511 & 45.6 & 429 & 608 \\
\hline Ruminating time, $\min / \mathrm{d}$ & 10 & 422 & 26.7 & 387 & 477 & 2 & 414 & 61.2 & 370 & 457 & 8 & 471 & 46.2 & 380 & 530 \\
\hline Pasture intake rate, $\mathrm{g}$ of $\mathrm{DM} / \mathrm{min}$ & 10 & 29.6 & 7.60 & 16.2 & 44.8 & 6 & 29.4 & 3.62 & 24.0 & 34.0 & 8 & 31.5 & 2.89 & 27.3 & 36.4 \\
\hline
\end{tabular}

${ }^{1} \mathrm{n}=$ number of data; Min = minimum; Max = maximum

${ }^{2} \mathrm{PM}$ above ground level in the $\mathrm{SPA}_{0}$ subset, above $3 \mathrm{~cm}$ in the $\mathrm{SPA}_{3}$ subset, and above $5 \mathrm{~cm}$ in the $\mathrm{SPA}_{5}$ subset.

${ }^{3}$ Pasture allowance above ground level in the $\mathrm{SPA}_{0}$ subset, above $3 \mathrm{~cm}$ in the $\mathrm{SPA}_{3}$ subset, and above $5 \mathrm{~cm}$ in the $\mathrm{SPA}_{5} \mathrm{subset}$

${ }^{4}$ Digestibility as given in the paper (i.e., in vitro or in vivo $\mathrm{OM}$ or $\mathrm{DM}$ digestibility). 
A)

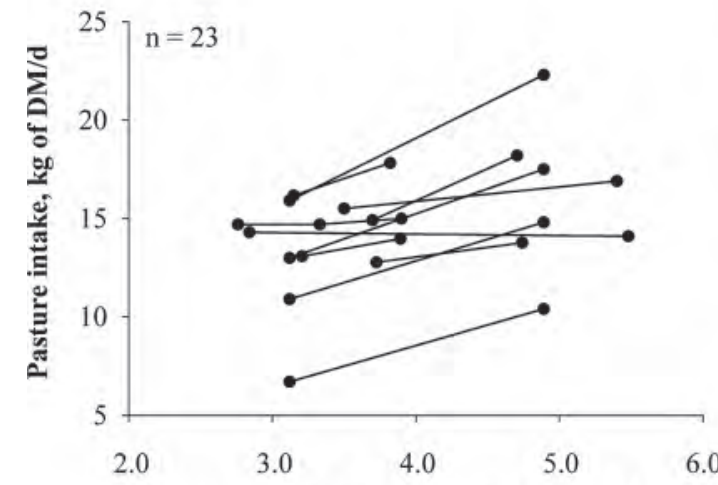

Pregrazing PM above ground level, $t$ of $\mathrm{DM} / \mathrm{ha}$

B)

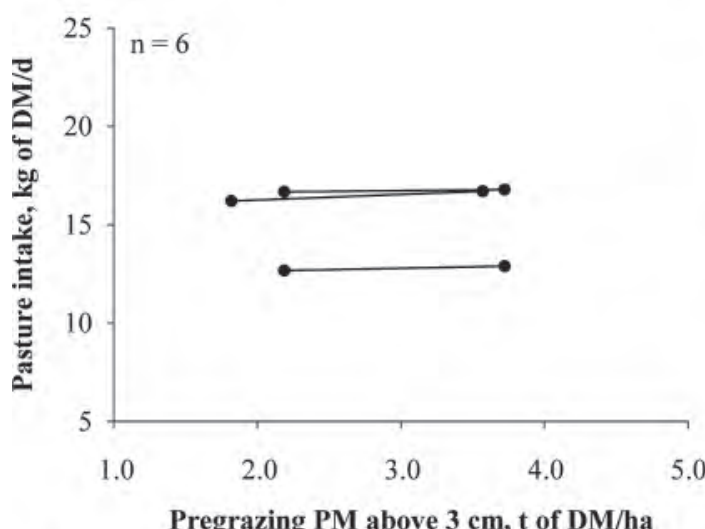

C)

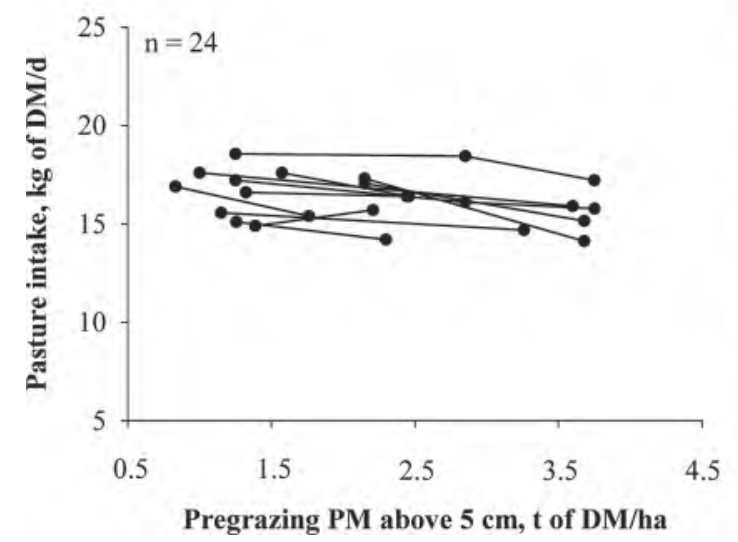

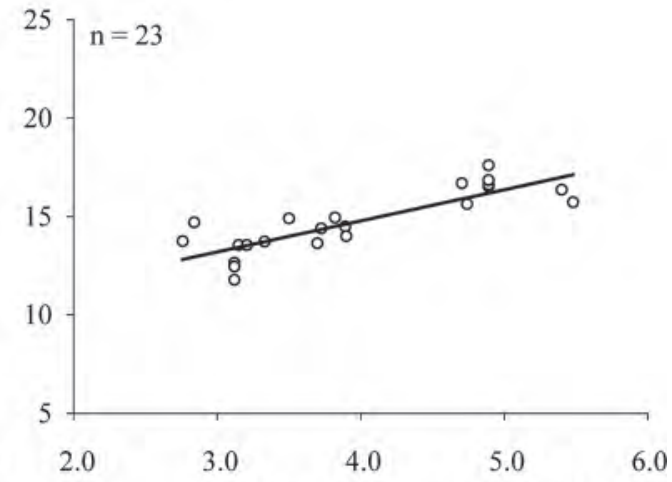

Pregrazing PM above ground level, t of DM/ha
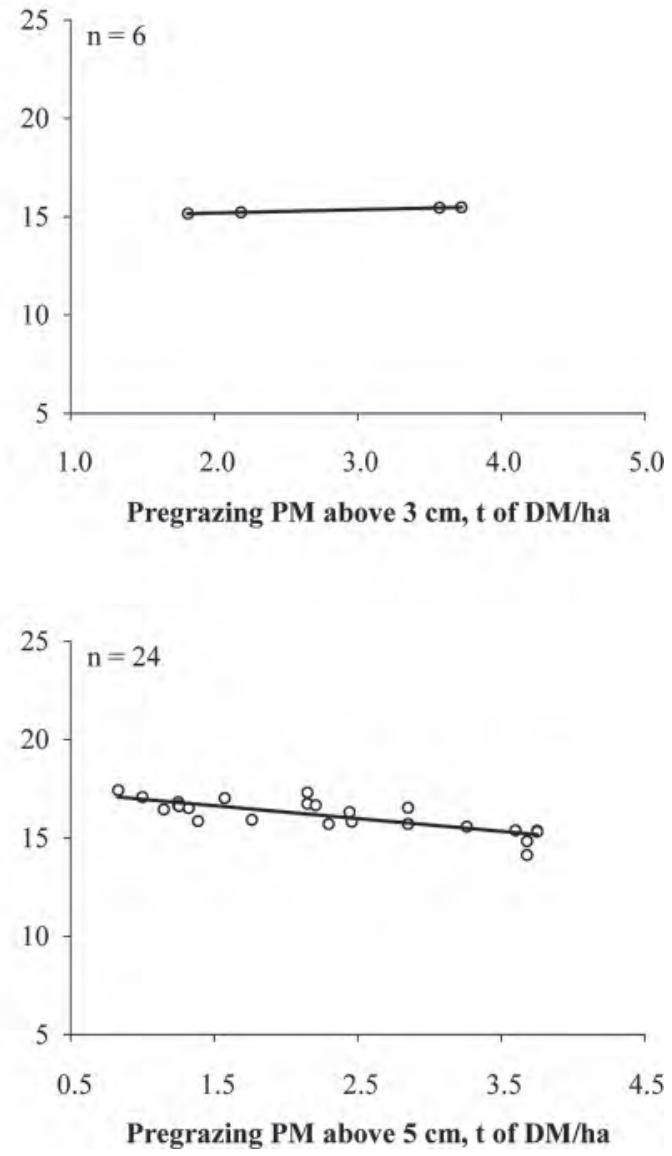

Figure 1. Effect of pregrazing pasture mass $(\mathrm{PM})$ on pasture intake of strip-grazing dairy cows when compared at the same pasture allowance (SPA): A) above ground level ( $\mathrm{SPA}_{0}$ subset), B) above $3 \mathrm{~cm}\left(\mathrm{SPA}_{3}\right.$ subset), and $\left.\mathrm{C}\right)$ above $5 \mathrm{~cm}\left(\mathrm{SPA}_{5}\right.$ subset). Plots on the left report raw data $(-)$ from each study included in the meta-analysis (1 line $=1$ PM comparison). Plots on the right report adjusted observations $(O)$ and the mean regression line from the mixed model analysis if $P<0.10\left(R_{y}=\mathrm{a}+\right.$ study $\left.+\mathrm{b} \times \mathrm{PM}\right)$.

\section{Effect of Pregrazing PM in the SPA ${ }_{5}$ Subset}

The mixed model was significant for pasture intake, milk production, and milk composition variables $(P<$
0.10; Table 3). With the exception of one result, all the PM comparisons in this subset presented a negative effect of PM on pasture intake (Figure 1C). On the basis of the predictive equations, pasture intake decreased on 
Table 3. Within-experiment relationship between pregrazing pasture mass (PM) and pasture intake, milk production, milk composition, and grazing behavior of strip-grazing dairy cows when compared at the same pasture allowance (SPA) above ground level $\left(\mathrm{SPA}_{0}\right.$ subset), above $3 \mathrm{~cm}\left(\mathrm{SPA}_{3}\right.$ subset), and above $5 \mathrm{~cm}\left(\mathrm{SPA}_{5}\right.$ subset) ${ }^{1}$

\begin{tabular}{|c|c|c|c|c|c|}
\hline Item & $\begin{array}{l}\text { No. } \\
\text { of data }\end{array}$ & $\mathrm{SD}$ & a & $\mathrm{b}$ & $\begin{array}{l}P \text {-value, } \\
\text { PM effect }\end{array}$ \\
\hline \multicolumn{6}{|l|}{$\mathrm{SPA}_{0}$ subset } \\
\hline Pasture intake, $\mathrm{kg}$ of $\mathrm{DM} / \mathrm{d}$ & 23 & 1.22 & 8.5 & 1.58 & 0.002 \\
\hline Milk production, $\mathrm{kg} / \mathrm{d}$ & 15 & 1.37 & 20.7 & 1.04 & 0.074 \\
\hline Grazing time, $\min / \mathrm{d}$ & 10 & 14.7 & 493 & -3.1 & 0.586 \\
\hline Pasture intake rate, $g$ of $\mathrm{DM} / \mathrm{min}$ & 10 & 1.91 & 9.9 & 4.83 & 0.004 \\
\hline \multicolumn{6}{|l|}{$\mathrm{SPA}_{3}$ subset } \\
\hline Pasture intake, $\mathrm{kg}$ of $\mathrm{DM} / \mathrm{d}$ & 6 & 0.01 & 14.8 & 0.17 & 0.116 \\
\hline Grazing time, $\min / \mathrm{d}$ & 6 & 4.5 & 583 & -22.0 & 0.063 \\
\hline Pasture intake rate, $\mathrm{g}$ of $\mathrm{DM} / \mathrm{min}$ & 6 & 0.88 & 24.8 & 1.63 & 0.073 \\
\hline \multicolumn{6}{|l|}{$\mathrm{SPA}_{5}$ subset } \\
\hline Pasture intake, $\mathrm{kg}$ of $\mathrm{DM} / \mathrm{d}$ & 24 & 0.64 & 17.6 & -0.65 & 0.002 \\
\hline Milk production, $\mathrm{kg} / \mathrm{d}$ & 29 & 0.70 & 22.3 & -1.09 & 0.003 \\
\hline Milk fat concentration, $\mathrm{g} / \mathrm{kg}$ & 23 & 1.41 & 37.0 & 0.88 & 0.080 \\
\hline Milk protein concentration, $\mathrm{g} / \mathrm{kg}$ & 23 & 0.37 & 33.3 & -0.16 & 0.320 \\
\hline $4 \%$ FCM production, $\mathrm{kg} / \mathrm{d}$ & 23 & 0.85 & 22.1 & -1.04 & 0.018 \\
\hline Milk fat production, $\mathrm{g} / \mathrm{d}$ & 23 & 41.8 & 850 & -32.7 & 0.064 \\
\hline Milk protein production, $\mathrm{g} / \mathrm{d}$ & 23 & 34.8 & 743 & -41.1 & 0.002 \\
\hline
\end{tabular}

average by $0.65 \mathrm{~kg} / \mathrm{t}$ of PM $(P<0.01)$. Production of milk, $4 \% \mathrm{FCM}$, and milk protein decreased by $1.09 \mathrm{~kg} / \mathrm{d}$ $(P<0.01 ;$ Figure $2 \mathrm{~B}), 1.04 \mathrm{~kg} / \mathrm{d}(P<0.05)$, and 41.1 $\mathrm{g} / \mathrm{d}(P<0.01)$ per tonne increase of $\mathrm{PM}$, respectively. Milk fat production tended to decrease with increasing PM ( $-33 \mathrm{~g} / \mathrm{d}$ per tonne of PM; $P=0.07$; Table 3$)$. Milk fat concentration tended to increase with increasing PM $(+0.9 \mathrm{~g} / \mathrm{kg}$ per tonne of PM; $P=0.09)$, and milk protein concentration was not affected by PM.

\section{Global Analysis (Slopes Database)}

Variation in pasture intake, milk production, and pasture intake rate with regard to pregrazing PM were affected by the estimation height (linear model: $P<$ 0.10; Table 4). Pasture intake increased with increasing $\mathrm{PM}$ at $\mathrm{SPA}_{0}(+1.7 \mathrm{~kg}$ of $\mathrm{DM} / \mathrm{d}$ per tonne of $\mathrm{PM})$, was not affected by PM at $\mathrm{SPA}_{3}$, and decreased with increasing $\mathrm{PM}$ at $\mathrm{SPA}_{5}(-0.8 \mathrm{~kg}$ of $\mathrm{DM} / \mathrm{d}$ per tonne of $\mathrm{PM})$. The pasture intake/PM slope was linearly affected by the estimation height $(P<0.001)$. Similarly, milk production increased by $1.23 \mathrm{~kg} / \mathrm{t}$ of $\mathrm{PM}$ at $\mathrm{SPA}_{0}$, did not vary at $\mathrm{SPA}_{3}$, and decreased by $0.92 \mathrm{~kg} / \mathrm{t}$ of $\mathrm{PM}$ at $\mathrm{SPA}_{5}$ (linear effect of estimation height, $P<0.01$ ). The effect of PM on pasture intake rate depended largely on the estimation height. Pasture intake rate increased greatly with increasing $\mathrm{PM}$ at $\mathrm{SPA}_{0}(+5.1 \mathrm{~g}$ of $\mathrm{DM} /$ min per tonne of $\mathrm{PM}$ ) but decreased with increasing $\mathrm{PM}$ at $\mathrm{SPA}_{5}(-1.8 \mathrm{~g}$ of $\mathrm{DM} / \mathrm{min}$ per tonne of $\mathrm{PM})$. At $\mathrm{SPA}_{3}$, pasture intake rate was not affected by PM. The effect of PM on grazing time was not affected by the estimation height.

\section{DISCUSSION}

The aim of the present work was to determine the quantitative effect of PM on pasture intake, milk production, milk composition, and grazing behavior of dairy cows under strip- or rotational-grazing management through an extensive literature review.

\section{Effect of PM Depends Largely on the Estimation Height}

According to the present meta-analysis, the effects of PM on pasture intake, milk production, and grazing behavior are directly related to the methodology used to estimate PM and thus PA. In studies in which PM were compared at $\mathrm{SPA}_{0}$, pasture intake increased by 1.3 to $3.6 \mathrm{~kg}$ of DM/t of PM (Stakelum, 1986a; Wales et al., 1999). Conversely, the effect of PM on pasture intake was negative in the experiments in which $\mathrm{PM}$ were compared at $\mathrm{SPA}_{5}(-0.4$ to $-0.6 \mathrm{~kg}$ of $\mathrm{DM} / \mathrm{t}$ of PM; Parga et al., 2002; Ribeiro Filho et al., 2003). The fact that the pasture intake/PM slope, in absolute value, was greater when $\mathrm{PM}$ were compared at $\mathrm{SPA}_{0}$ than at $\mathrm{SPA}_{5}$ suggests that the effects of $\mathrm{PM}$ on pasture intake can be better highlighted at $\mathrm{SPA}_{0}$ rather than at $\mathrm{SPA}_{5}$. It is difficult to underline a variation in pasture intake if the difference is lower than $1 \mathrm{~kg}$ of $\mathrm{DM} / \mathrm{d}$ between treatments. Consequently, a range of $1 \mathrm{t}$ of $\mathrm{DM} /$ ha between $2 \mathrm{PM}$ may be sufficient to find a significant effect of $\mathrm{PM}$ on pasture intake when compared at $\mathrm{SPA}_{0}$, but probably not at $\mathrm{SPA}_{5}$. According to the review by Delagarde et al. (2001) and the hypothesis 
Table 4. Global analysis of the effect of pregrazing pasture mass (PM) on pasture intake, milk production, and grazing behavior of strip-grazing dairy cows when compared at the same pasture allowance (SPA) above different estimation heights $(\mathrm{EH})$ : above ground level $\left(\mathrm{SPA}_{0}\right)$, above 3 $\mathrm{cm}\left(\mathrm{SPA}_{3}\right)$, and above $5 \mathrm{~cm}\left(\mathrm{SPA}_{5}\right)$

\begin{tabular}{|c|c|c|c|c|c|c|c|}
\hline Slope & No. of data & \multicolumn{3}{|c|}{$\mathrm{PM}$} & SD & \multicolumn{2}{|c|}{$P$-value, EH effect } \\
\hline Pasture intake, $\mathrm{kg}$ of $\mathrm{DM} / \mathrm{d}$ per tonne of $\mathrm{PM}$ & 25 & 1.74 & 0.21 & -0.81 & 0.983 & $<0.001$ & 0.904 \\
\hline Pasture intake rate, $\mathrm{g}$ of $\mathrm{DM} / \mathrm{min}$ per tonne of $\mathrm{PM}$ & 12 & 5.12 & 0.95 & -1.83 & 1.839 & $<0.001$ & 0.466 \\
\hline
\end{tabular}

of the GrazeIn model to predict pasture intake of dairy cows (Delagarde et al., 2011a), PM should have no effect on pasture intake when PM are compared at the SPA above an intermediate height (i.e., above 2 to 3 $\mathrm{cm})$. Although few results were available $(\mathrm{n}=6)$ in the literature, this hypothesis was confirmed in the present meta-analysis, in which pasture intake was not affected by PM when PM were compared at $\mathrm{SPA}_{3}$.

\section{A)}

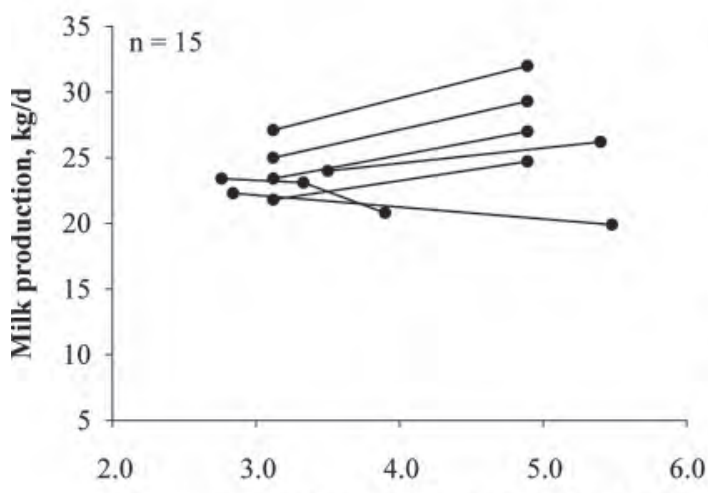

Pregrazing PM above ground level, $t$ of DM/ha

B)

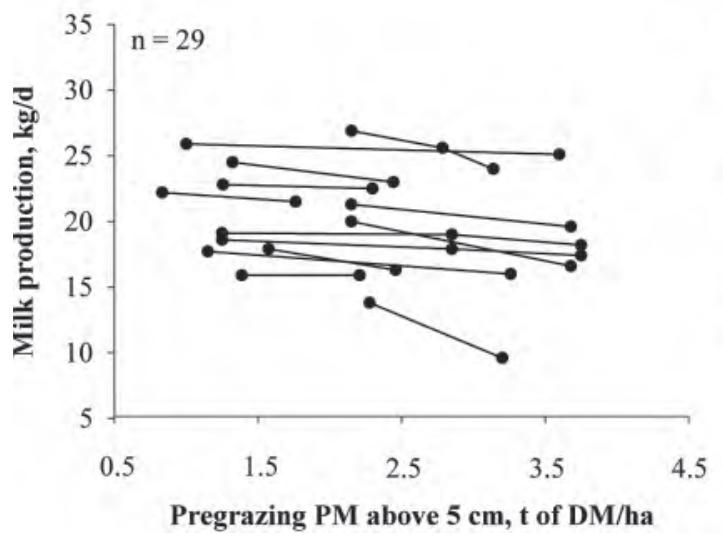

These results were not related to the country or the method used to estimate pasture intake because the effect of PM on pasture intake was always related to the estimation height even within the same country. As an example, the positive effect of PM at $\mathrm{SPA}_{0}$ has been observed in Ireland and Australia when using both the $n$-alkanes technique and the cutting technique for measuring pasture intake (Stakelum, 1986a,b; Wales
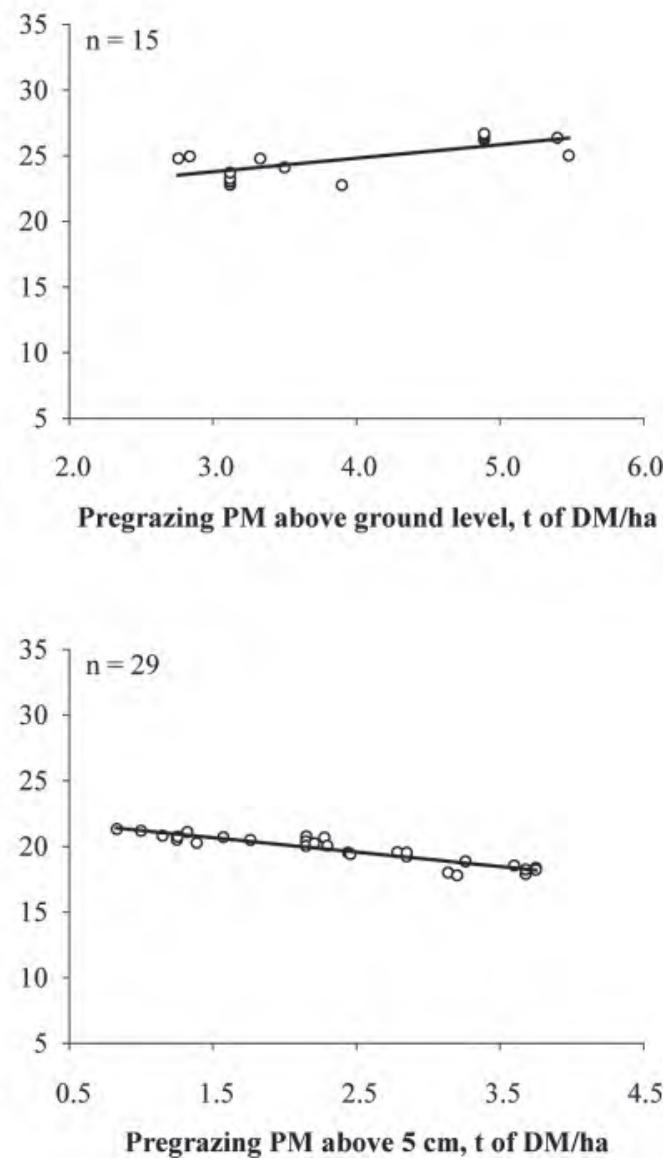

Figure 2. Effect of pregrazing pasture mass $(\mathrm{PM})$ on milk production of strip-grazing dairy cows when compared at the same pasture allowance (SPA): A) above ground level ( $\mathrm{SPA}_{0}$ subset), and B) above $5 \mathrm{~cm}\left(\mathrm{SPA}_{5}\right.$ subset). Plots on the left report raw data (-) from each study included in the meta-analysis ( 1 line $=1 \mathrm{PM}$ comparison). Plots on the right report adjusted observations $(O)$ and the mean regression line from the mixed model analysis if $P<0.10\left(R_{y}=\mathrm{a}+\right.$ study $\left.+\mathrm{b} \times \mathrm{PM}\right)$. 
et al., 1999; Stakelum and Dillon, 2007). This is also clearly illustrated in the recent study by Pérez-Prieto et al. (2012), in which 2 different PM were compared simultaneously at $\mathrm{SPA}_{0}, \mathrm{SPA}_{3}$, and $\mathrm{SPA}_{5}$. This trial was conducted in France, and pasture intake was estimated using the $n$-alkanes technique. The effect of PM on pasture intake was positive $(0.74 \mathrm{~kg}$ of $\mathrm{DM} / \mathrm{t}$ of $\mathrm{PM})$, nil, and negative $(-0.65 \mathrm{~kg}$ of $\mathrm{DM} / \mathrm{t}$ of $\mathrm{PM})$ when $\mathrm{PM}$ were compared at $\mathrm{SPA}_{0}, \mathrm{SPA}_{3}$, and $\mathrm{SPA}_{5}$, respectively.

The global analysis in the present investigation demonstrated the interaction between PM and estimation height, with the slope between pasture intake and PM decreasing linearly from +1.74 to $-0.81 \mathrm{~kg}$ of $\mathrm{DM} / \mathrm{t}$ of $\mathrm{PM}$ when the estimation height increased from 0 to 5 $\mathrm{cm}$. This was consistent with milk production, which also increased, was unaltered, and decreased when PM were compared at $\mathrm{SPA}_{0}, \mathrm{SPA}_{3}$, and $\mathrm{SPA}_{5}$, respectively. According to the conceptual approach of Delagarde et al. (2011a), this interaction may be because, under a wide range of $\mathrm{PM}$, both the $\mathrm{PA}$ above ground level and the PA above $5 \mathrm{~cm}$ are unreliable estimators of the pasture actually available to cows. It is known that cows are unable to reach ground level while grazing, even under very severe grazing conditions, and evidence exists to suggest that they can graze below $5 \mathrm{~cm}$ to a postgrazing plate meter sward height of 2 to $3 \mathrm{~cm}$ (Stockdale, 1996; Lee et al., 2007; Pérez-Prieto et al., 2011). Assuming that pasture below 2 to $3 \mathrm{~cm}$ is ungrazable and that pasture between 2 to $3 \mathrm{~cm}$ and $5 \mathrm{~cm}$ is grazable, it can be assumed that PA above 2 to 3 $\mathrm{cm}$ would be a better estimator of the pasture actually available to cows. In the experiment by Pérez-Prieto et al. (2012), PM above $2.5 \mathrm{~cm}$ was directly measured and enabled the calculation of PA above $2.5 \mathrm{~cm}$. When PM were compared at $\mathrm{SPA}_{0}$, the ungrazable stratum (below 2 to $3 \mathrm{~cm}$ ) was quantitatively greater at low PM rather than at high PM because of the larger offered area at low PM. Pasture availability was, therefore, lower at low PM rather than at high PM (17 vs. $24 \mathrm{~kg}$ of DM/d of PA above $2.5 \mathrm{~cm}$ ), explaining the positive effect of $\mathrm{PM}$ on pasture intake at $\mathrm{SPA}_{0}$. In contrast, when PM were compared at $\mathrm{SPA}_{5}$, the grazable stratum (between 2 to 3 and $5 \mathrm{~cm}$ ) was quantitatively greater at low PM rather than at high PM because of the larger area offered at low PM. Pasture availability was greater at low PM rather than at high PM (31 vs. $20 \mathrm{~kg}$ of DM of PA above $2.5 \mathrm{~cm}$ ), explaining the negative effect of PM. Pasture intake was not affected by PM when pasture availability was similar between low and high $\mathrm{PM}$, that is, when $\mathrm{PM}$ were compared at $\mathrm{SPA}_{3}(23$ vs. $23 \mathrm{~kg}$ of $\mathrm{DM} / \mathrm{d}$ of PA above $2.5 \mathrm{~cm}$ ). Graphical and conceptual representations of this approach can be found in Delagarde et al. (2011a) and Pérez-Prieto et al. (2012). In perennial ryegrass-based pastures, it can thus be recommended to measure PA above 2 to $3 \mathrm{~cm}$ to accurately estimate the amount of pasture actually available to cows over a wide range of PM.

\section{Behavioral Adaptation to PM Variation}

When PM changes do not affect pasture quality, as in the studies included in the present meta-analysis, the effect of PM on intake is expected to be related to nonnutritional intake regulation (i.e., behavioral adaptation to pasture availability; Poppi et al., 1987). According to the predictive equations, the effect of PM on pasture intake mainly appeared to be related to variation in pasture intake rate, with grazing time not being affected ( $\mathrm{SPA}_{0}$ subset) or being only slightly affected $\left(\mathrm{SPA}_{3}\right.$ subset) by PM. The $\mathrm{SPA}_{5}$ subset had no significant equation for grazing time because of inconsistent results on the effect of PM.

In the $\mathrm{SPA}_{0}$ subset, the large increase in pasture intake rate with increasing $\mathrm{PM}$ ( $5 \mathrm{~g}$ of $\mathrm{DM} / \mathrm{min}$ per tonne of PM) was consistent with results previously reported for dairy cows continuously grazing on temperate grasslands at different sward surface heights (Rook et al., 1994; Gibb et al., 1997). In such grazing systems, grazing time is generally increased as a compensatory response to the reduction in pasture intake rate with decreasing PM. Indeed, cows can graze for more than $700 \mathrm{~min} / \mathrm{d}$ to compensate for the low pasture intake rate caused by very short swards (4 to $6 \mathrm{~cm}$, plate meter; Hodgson, 1986; Rook et al., 1994). Under continuously stocked management, pasture availability in terms of kilograms of DM per day per cow is theoretically unlimited because of the large area offered and low instantaneous stocking rate. Furthermore, sward height is not reduced throughout the day, and cows consume only the upper leafy strata (Gibb et al., 1997). Grazing conditions are thus relatively easy throughout the day, allowing cows to extend their grazing time (Rook et al., 1994; Prache and Peyraud, 1997; Parga et al., 2000). In contrast, under strip- or rotational-grazing management, a grazing time of more than $600 \mathrm{~min} / \mathrm{d}$ has seldom been recorded (Bargo et al., 2002; Kennedy et al., 2007; Stakelum and Dillon, 2007), and grazing time generally averages between 450 and $550 \mathrm{~min} / \mathrm{d}$. Indeed, under such conditions, cows are forced to graze lower into the sward profile because of the restricted area offered daily, leading to more difficult grazing conditions and a lower pasture intake rate at night compared with the morning (Barrett et al., 2001). In the process of grazing down a sward shorter and shorter, the intake becomes increasingly predominated by pseudostem and dead material, probably reducing the motivation of cows to 
keep on grazing and thus limiting the grazing time. Conversely, under continuous-grazing management, pasture intake rate may even increase throughout the day because of increased pasture DM and soluble carbohydrate concentrations (Gibb et al., 1998; Gregorini, 2012). The meta-analysis presented here thus seems to demonstrate different behavioral adaptations in cows on a daily basis according to changes in PM between rotational and continuously stocked grazing management systems.

According to the global analysis, the decrease in pasture intake with increasing PM in the $\mathrm{SPA}_{5}$ subset was related, at least partially, to the reduction in pasture intake rate $(-2 \mathrm{~g}$ of $\mathrm{DM} / \mathrm{min}$ per tonne of $\mathrm{PM})$. No significant equation was obtained for grazing time because results noted in the literature were inconsistent, with both positive and negative effects of PM on grazing time being reported. The reduction in pasture intake rate with increasing PM appears to contradict the numerous results obtained in short-term experiments, which all showed a positive and strong relationship between pasture intake rate and $\mathrm{PM}$ on a minute to hour basis (Hodgson, 1986; Rook et al., 1994; Gibb et al., 1997). On a daily basis, PM has also been reported to affect pasture intake rate positively when $\mathrm{PM}$ are compared at $\mathrm{SPA}_{0}\left(\mathrm{SPA}_{0}\right.$ subset; Wales et al., 1999; Pérez-Prieto et al., 2012). This clearly indicates that, under strip- or rotational-grazing management, average daily grazing behavior cannot be predicted from a single description of pregrazing pasture characteristics (e.g., PM or sward height). Pregrazing pasture descriptions do not include grazing conditions for the entire grazing-down process, given that grazing conditions during the second half of this process are far more difficult than those in the first hours of grazing (Barrett et al., 2001). Average daily pasture intake rate should be considered as an integrated variable, which takes into account pasture availability from early morning until late at night. When a new strip of fresh pasture is available in the morning, it can be hypothesized that immediate pasture intake rate is greater at high PM rather than at low PM because of the greater bite mass (Barrett et al., 2001). At the end of the day, cows at high PM are forced to graze the stem and pseudostem layer, previously identified as a major source of resistance for pasture intake (Wade, 1991). Indeed, in studies by Ribeiro Filho et al. (2003) and Pérez-Prieto et al. (2012), sheath defoliation depth was 3 to 4 times greater, and sheath defoliation volume (defoliation depth $\times$ offered area) was almost twice as great at high PM rather than at low PM when compared with similar PA above $5 \mathrm{~cm}$. This suggests that the time spent grazing sheath strata is much longer at high PM than at low PM, probably reducing pasture intake rate despite the higher postgrazing sward height.
During the second half of the day, a much lower instantaneous pasture intake rate can thus be expected at high PM rather than at low PM, to achieve an average pasture intake rate lower at high PM than at low PM.

When PM are compared at $\mathrm{SPA}_{3}\left(\mathrm{SPA}_{3}\right.$ subset), the absence of any effect of PM on pasture intake was related to low variation in both grazing time and pasture intake rate. According to the predictive equations, a compensatory process appears to take place in which the apparent reduction in pasture intake rate with decreasing PM is compensated for by a tendency to increase the grazing time. Consequently, it can be suggested that grazing conditions between PM are almost similar when PM are compared at $\mathrm{SPA}_{3}$, with the difference between low and high PM being compensated for by the difference between areas offered daily in each PM. This is clearly observed in the experiment by Pérez-Prieto et al. (2012), in which postgrazing extended lamina height, a variable recognized as an accurate estimator of grazing severity (Wade, 1991), was similar between low and high PM only when compared at $\mathrm{SPA}_{3}$.

\section{Practical Implications}

The present work has established, statistically, that the effects of PM on pasture intake, milk production, and grazing behavior depend on the cutting height above which PM and PA are estimated. The results of this meta-analysis thus corroborate the only other experiment carried out to demonstrate this interaction between PM and the estimation height (Pérez-Prieto et al., 2012). The primary practical implication resulting from this investigation is that part of the variation in pasture intake, attributed to changes in PM, is due to the methodological choice for conducting the experiment. In this respect, any treatment affecting pregrazing PM directly or indirectly, such as sward type or fertilization level, can affect intake, depending on the methodology used for estimating PM and PA. The final effect of a treatment on pasture intake will, therefore, be a combination of the treatment effect per se and of the indirect effect of PM resulting from different methodological approaches. To avoid such confusion and possible misinterpretations of results, PM should be compared at similar levels of pasture availability (i.e., at the SPA above 2 to $3 \mathrm{~cm}$ ). The choice of the researcher to work at $\mathrm{SPA}_{0}$ or $\mathrm{SPA}_{5}$ is, therefore, decisive for the experimental outcome. Consequently, under strip- or rotational-grazing management, it may be strongly recommended that treatments with different PM be compared at similar levels of pasture availability (i.e., $\mathrm{SPA}_{3}$ ). 
According to our results, PM had no effect on pasture intake and milk production when PM were compared at $\mathrm{SPA}_{3}$. However, the 3 studies included in this subset were short-term experiments (approximately 1 to $3 \mathrm{mo}$ ), and it would be interesting to confirm these results in the long term, specifically, during the entire grazing season or over several successive grazing seasons. When a grazing season is considered, pregrazing PM is mainly controlled by the grazing rotation length. Experiments studying the effects of grazing rotation length are, however, scarce and date back more than 20 to 30 yr (McFeely et al., 1975; Leaver, 1985). In the experiment by McFeely et al. (1975) and according to the comprehensive review by Leaver (1985), grazing rotation length does not appear to affect the performance of dairy cows under strip- or rotational-grazing management, corroborating results obtained in the present meta-analysis.

Models to predict pasture intake by grazing dairy cows were reviewed by Delagarde and O'Donovan (2005). In their review, the effect of PM was not clearly established in most of the existing models. The equations reported in the present meta-analysis may, therefore, be useful in determining the effect of PM in models in which the effects of PM and PA are considered either above ground level or at 2, 3, 4, or $5 \mathrm{~cm}$ above ground level. For example, the GrazeIn model (Delagarde et al., 2011a) includes no effect of PM on pasture intake because PM and PA are standardized above $2 \mathrm{~cm}$. The Diet Check model (Heard et al., 2004) considers a positive effect of PM or compressed sward height on pasture intake because PM is measured at ground level. These 2 modeling options are consistent with the height at which PM is considered in their respective models, and both are consistent with the results of this meta-analysis. A predictive model based on PM and PA determined above $5 \mathrm{~cm}$ should necessarily include a negative effect of PM on pasture intake.

The meta-analysis presented here focused on dairy cows grazing on temperate pastures. The transferability of these results to experiments using other types of ruminants (e.g., young cattle, sheep, or goats) or other types of pastures (e.g., tropical grasslands) is unknown. It is probable that the threshold height of 2 to $3 \mathrm{~cm}$ is not adequate to determine pasture availability for animals being able to graze lower into the sward profile. Similarly, the morphological characteristics of the pasture probably play an important role in determining the height at which pasture availability should be defined, with swards richer in stem and pseudostem being more difficult to graze.

\section{CONCLUSIONS}

The present meta-analysis has facilitated the understanding of the contradictory results reported previously on the effect of PM on pasture intake, milk production, and grazing behavior of dairy cows when PM were compared at similar PA under strip- or rotational-grazing management. The positive, absence of, or negative effect of PM found in the literature can now be clearly attributed to the methodology used to compare PM, namely, the height at which PM and PA are measured. Pasture intake and milk production responses to PM in relation to the estimation height vary primarily because of pasture intake rate because grazing time displayed only low variation with regard to PM irrespective of the estimation height. This study has important implications for future grazing research and the interpretation of results for modeling the intake, performance, and behavior of grazing dairy cows and for improving grazing management in pasture-based dairy systems. Both PA above ground level and PA above $5 \mathrm{~cm}$ were unreliable estimators of the pasture actually available to cows under a wide range of PM. To avoid possible misinterpretations of results, it is thus recommended that ryegrass-based pastures be compared with different PM at the SPA above 2 to $3 \mathrm{~cm}$, which is the best estimate of the actual available pasture.

\section{ACKNOWLEDGMENTS}

The financial support of both the Comisión Nacional de Investigación Científica y Tecnológica (CONICYT, Santiago, Chile) and the French Embassy (Santiago, Chile) in the form of the first author's PhD scholarship are gratefully acknowledged. We thank Luc Delaby (UMR1348 INRA-Agrocampus Ouest PEGASE, SaintGilles, France) for statistical assistance during the preparation of the manuscript. Caractères et caetera (Rennes, France) postedited the English style.

\section{REFERENCES}

Bargo, F., L. D. Muller, J. E. Delahoy, and T. W. Cassidy. 2002. Milk response to concentrate supplementation of high producing dairy cows grazing at two pasture allowances. J. Dairy Sci. 85:17771792 .

Barrett, P. D., A. S. Laidlaw, C. S. Mayne, and H. Christie. 2001. Pattern of herbage intake rate and bite dimensions of rotationally grazed dairy cows as sward height declines. Grass Forage Sci. $56: 362-373$

Baudracco, J., N. Lopez-Villalobos, L. A. Romero, D. Scandolo, M. Maciel, E. A. Comerón, C. W. Holmes, and T. N. Barry. 2011. Effects of stocking rate on pasture production, milk production and reproduction of supplemented crossbred Holstein-Jersey dairy cows grazing lucerne pasture. Anim. Feed Sci. Technol. 168:131-143. 
Christie, H., C. S. Mayne, A. S. Laidlaw, D. M. Patterson, and D. A. McGilloway. 2000. Effect of sward manipulation and milk potential on herbage intake of grazing dairy cows. Pages 79-84 in Grazing Management. Occas. Symp. No. 34. A. J. Rook and P. D. Penning, ed. Br. Grassl. Soc., Reading, UK.

Curran, J., L. Delaby, E. Kennedy, J. P. Murphy, T. M. Boland, and M. O'Donovan. 2010. Sward characteristics, grass dry matter intake and milk production performance are affected by pre-grazing herbage mass and pasture allowance. Livest. Sci. 127:144-154.

Dalley, D. E., J. R. Roche, C. Grainger, and P. J. Moate. 1999. Dry matter intake, nutrient selection and milk production of dairy cows rainfed perennial pastures at different herbage allowances in spring. Aust. J. Exp. Agric. 39:923-931.

Delagarde, R., P. Faverdin, C. Baratte, and J. L. Peyraud. 2011a. GrazeIn: A model of herbage intake and milk production for grazing dairy cows. 2. Prediction of intake under rotational and continuously stocked grazing management. Grass Forage Sci. 66:45-60.

Delagarde, R., and M. O'Donovan. 2005. Les modèles de prévision de l'ingestion journalière d'herbe et de la production laitière des vaches au pâturage. Prod. Anim. 18:241-253.

Delagarde, R., J. L. Peyraud, and L. Delaby. 2004. High grazing pressure in early-spring increases herbage intake of grazing dairy cows in late-spring. Pages 647-649 in Land Use Systems in Grassland Dominated Regions. Proc. 19th Gen. Mtg. Eur. Grassl. Fed., Luzern, Switzerland. A. Lüscher, B. Jeangros, W. Kessler, O. Huguenin, M. Lobsiger, N. Millar, and D. Suter, ed. Br. Grassl. Soc., Reading, UK.

Delagarde, R., S. Prache, P. D'Hour, and M. Petit. 2001. Ingestion de l'herbe par les ruminants au pâturage. Fourrages 166:189-212.

Delagarde, R., H. Valk, C. S. Mayne, A. J. Rook, A. González-Rodríguez, C. Baratte, P. Faverdin, and J. L. Peyraud. 2011b. GrazeIn: A model of herbage intake and milk production for grazing dairy cows. 3. Simulations and external validation of the model. Grass Forage Sci. 66:61-77.

Dillon, P., J. R. Roche, L. Shalloo, and B. Horan. 2005. Optimising financial return from grazing in temperate pastures. Pages 131-147 in Proc. Satellite Workshop 20th Int. Grassl. Congr., Cork, Ireland. Utilization of Grazed Grass in Temperate Animal. Systems. J. J. Murphy, ed. Wageningen Academic Publishers, Wageningen, the Netherlands.

Gibb, M. J., C. A. Huckle, and R. Nuthall. 1998. Effect of time of day on grazing behaviour by lactating dairy cows. Grass Forage Sci. $53: 41-46$.

Gibb, M. J., C. A. Huckle, R. Nuthall, and A. J. Rook. 1997. Effect of sward surface height on intake and grazing behaviour by lactating Holstein Friesian cows. Grass Forage Sci. 52:309-321.

Gregorini, P. 2012. Diurnal grazing pattern: Its physiological basis and strategic management. Anim. Prod. Sci. 52:416-430. http:// dx.doi.org/10.1071/AN11250.

Heard, J. W., D. C. Cohen, P. T. Doyle, W. J. Wales, and C. R. Stockdale. 2004. Diet Check-A tactical decision support tool for feeding decisions with grazing dairy cows. Anim. Feed Sci. Technol. 112:177-194.

Hodgson, J. 1986. Grazing behaviour and herbage intake. Pages 51-64 in Grazing. Occas. Symp. No. 19. J. Frame, ed. Br. Grassl. Soc., Reading, UK.

Holmes, C. W., C. J. Hoogendoorn, M. P. Ryan, and A. C. P. Chu. 1992. Some effects of herbage composition, as influenced by previous grazing management, on milk production by cows grazing on ryegrass/white clover pastures. I. Milk production in early spring: Effects of different regrowth intervals during the preceding winter period. Grass Forage Sci. 47:309-315.

INRA (French National Institute for Agricultural Research). 2007. Alimentation des bovins, ovins et caprins: Besoins des animaux - Valeurs des aliments. Editions QUAE, Versailles, France.

Kennedy, E., M. O'Donovan, J. P. Murphy, L. Delaby, and F. P. O'Mara. 2007. Effect of spring grazing date and stocking rate on sward characteristics and dairy cow production during midlactation. J. Dairy Sci. 90:2035-2046.

Leaver, J. D. 1985. Milk production from grazed temperate grassland. J. Dairy Res. 52:313-344.
Lee, J. M., D. J. Donaghy, and J. R. Roche. 2007. The effect of grazing severity and fertiliser application during winter on herbage regrowth and quality of perennial ryegrass (Lolium perenne L.). Aust. J. Exp. Agric. 47:825-832.

Lee, J. M., D. J. Donaghy, and J. R. Roche. 2008. Effect of postgrazing residual pasture height on milk production. J. Dairy Sci. 91:4307-4311.

Maher, J., G. Stakelum, and M. Rath. 2003. Effect of daily herbage allowance on the performance of spring-calving dairy cows. Ir. J. Agric. Food Res. 42:229-241.

McEvoy, M., L. Delaby, J. P. Murphy, T. M. Boland, and M. O'Donovan. 2010. Effect of herbage mass and allowance on sward characteristics, milk production, intake and rumen volatile fatty acid concentration. Grass Forage Sci. 65:335-347.

McFeely, P. C., D. Browne, and O. Carty. 1975. Effect of grazing interval and stocking rate on milk production and pasture yield. Isr. J. Agric. Res. 14:309-319.

Parga, J., J. L. Peyraud, and R. Delagarde. 2000. Effect of sward structure and herbage allowance on herbage intake and digestion by strip-grazing dairy cows. Pages 61-66 in Grazing Management. Occas. Symp. No. 34. A. J. Rook and P. D. Penning, ed. Br. Grassl. Soc., Reading, UK.

Parga, J., J. L. Peyraud, and R. Delagarde. 2002. Age of regrowth affects grass intake and ruminal fermentations in grazing dairy cows. Pages 256-257 in Multi-function Grasslands: Quality Forages, Animal Products and Landscapes. Proc. 19th Gen. Mtg. Eur. Grassl. Fed., La Rochelle, France. J. L. Durand, J. C. Emile, C. Huyghe and G. Lemaire, ed. British Grassland Society, Reading, UK.

Pérez-Prieto, L. A., J. L. Peyraud, and R. Delagarde. 2011. Pasture intake, milk production and grazing behaviour of dairy cows grazing low-mass pastures at three daily allowances in winter. Livest. Sci. 137:151-160

Pérez-Prieto, L. A., J. L. Peyraud, and R. Delagarde. 2012. Does pregrazing herbage mass really affect herbage intake and milk production of strip-grazing dairy cows? Grass Forage Sci. http://dx.doi. org $/ 10.1111 / \mathrm{j} .1365-2494.2012 .00876 . x$.

Peyraud, J. L., E. A. Comerón, M. H. Wade, and G. Lemaire. 1996. The effect of daily herbage allowance, herbage mass and animal factors upon herbage intake by grazing dairy cows. Ann. Zootech. 45:201-217.

Poppi, D. P., T. P. Hughes, and P. J. L'Huillier. 1987. Intake of pasture by grazing ruminants. Pages $55-63$ in Feeding Livestock on Pasture. A. M. Nicol, ed. Publ. No. 10. N. Z. Soc. Anim. Prod, Lincoln University, Lincoln, New Zealand.

Prache, S., and J. L. Peyraud. 1997. Préhensibilité de l'herbe pâturée chez les bovins et les ovins. INRA Prod. Anim. 10:377-390.

Ribeiro Filho, H. M. N., R. Delagarde, and J. L. Peyraud. 2003. Inclusion of white clover in strip-grazed perennial ryegrass swards: Herbage intake and milk yield of dairy cows at different ages of sward regrowth. Anim. Sci. 77:499-510.

Rook, A. J., C. A. Huckle, and P. D. Penning. 1994. Effects of sward height and concentrate supplementation on the ingestive behaviour of spring-calving dairy cows grazing grass-clover swards. Appl. Anim. Behav. Sci. 40:101-112.

SAS Institute. 1999. SAS User's Guide: Statistics. SAS Inst. Inc., Cary, NC.

Stakelum, G. 1986a. Herbage intake of grazing dairy cows. 2. Effect of herbage allowance, herbage mass and concentrate feeding on the intake of cows grazing primary spring grass. Isr. J. Agric. Res. 25:41-51

Stakelum, G. 1986b. Herbage intake of grazing dairy cows. 3. Effects of herbage mass, herbage allowance and concentrate feeding on the herbage intake of dairy cows grazing on mid-summer pasture. Isr. J. Agric. Res. 25:179-189.

Stakelum, G., and P. Dillon. 2004. The effect of herbage mass and allowance on herbage intake, diet composition and ingestive behaviour of dairy cows. Ir. J. Agric. Food Res. 43:17-30.

Stakelum, G., and P. Dillon. 2007. The effect of grazing pressure on rotationally grazed pastures in spring/early summer on the performance of dairy cows in the summer/autumn period. Ir. J. Agric. Food Res. 46:29-46. 
Stockdale, C. R. 1996. Substitution and production responses when lactating dairy cows graze a white clover pasture supplemented with maize silage. Aust. J. Exp. Agric. 36:771-776.

St-Pierre, N. R. 2001. Integrating quantitative findings from multiple studies using mixed model methodology. J. Dairy Sci. 84:741-755.

Ungar, E. D. 1996. Ingestive behaviour. Pages 185-218 in The Ecology and Management of Grazing Systems. J. Hodgson and A. W. Illius, ed. CAB Int., Wallingford.

Wade, M. H. 1991. Factors affecting the availability of vegetative $L o$ lium perenne to grazing dairy cows with special reference to sward characteristics, stocking rate and grazing method. PhD Thesis. Université de Rennes 1, Rennes, France.
Wales, W. J., P. T. Doyle, C. R. Stockdale, and D. W. Dellow. 1999 Effects of variations in herbage mass, allowance, and level of supplement on nutrient intake and milk production of dairy cows in spring and summer. Aust. J. Exp. Agric. 39:119-130.

Wims, C. M., M. H. Deighton, E. Lewis, B. O'Loughlin, L. Delaby, T. M. Boland, and M. O'Donovan. 2010. Effect of pre-grazing herbage mass on methane production, dry matter intake, and milk production of grazing dairy cows during the mid-season period. J. Dairy Sci. 93:4976-4985. 